\title{
Models for Investigating the Effectiveness of the Citizens Mediation Centre in the Resolution of Landlord/Landlady- Tenant Disputes in Lagos State, Nigeria
}

\author{
Kasumu, Taiwo Olufemi \\ Department of Sociology College of Business and Social Sciences Covenant University, Ota, Ogun State, \\ Nigeria
}

\section{INTRODUCTION}

Lagos State is regarded as Nigeria's largest commercial nerve centre with a huge population that is arguably the largest in Nigeria. This is arguable because official statistics continues to confer the title of the largest state in the country on Kano State based on the country's 2006 Census figures while the Lagos State Government, on the other hand, following its own Census conducted the same year, considers the state the largest in the country in terms of human population. The state boasts a population exceeding 21 million residents as at 2014 (Adelaja, 2014; Lagos State Government, 2014). The Lagos' economy is also international in nature because the state shares borders with many West African countries such as Benin Republic. Through the same border post, West Africans such as Ghanaians, Beninese, Togolese and others flock to Nigeria weekly or frequently for business. Some buy huge products made in Nigeria to be resold in their countries while others bring their wares to large Lagos markets for sale. As members of the Economic Community of West African States, these foreign nationals find it easy to enter and exit Nigerian borders through Lagos. With high technology access, residents in the state also conduct their businesses with the outside world on a larger scale than residents in many other Nigerian states.

The inability of government to meet the housing needs of residents in the state has resulted in the dominance by a private rental sector which provides about $72 \%$ of the housing needs of Lagosians (Economist Intelligence Unit, 2012). In the area of housing, there is a shortfall in the required number of housing units that would meet the residential and commercial needs of residents. The extent of the housing shortage in Lagos is enormous. The inadequacies are far reaching and the deficit is both quantitative and qualitative. Citing the Lagos Household Survey (2011), the Economist Intelligence Unit (2012) posits that about $72 \%$ of Lagos residents are tenants paying rent as high as 50\% of their monthly incomes; while most of the existing accommodations are provided by private-sector landlords. The survey further states that only $18 \%$ owned their dwelling units while 10\% are free occupants, with no rental payment. Yet, of the 7,850 housing units built by the state government between year 2000 till date, there is a shortfall from the projection of 224,000 housing units annually by the Ministry of Housing (Economist Intelligence Unit, 2012).

Since public or social-sector housing is not enough to meet the housing and business needs of citizens, private-sector landlords appear to enjoy an oligopolistic advantage that protects and advances their interests as against the interests of their tenants. This is the trend in other parts of the developing and developed world (UNHabitat, 2006). Exploiting this situation, many Lagos' landlords offer a take-it-or-leave-it rental system that demands high rents but presents low quality rental properties with some having mediocre facilities (Wahab \& Adetunji, 2015; Wahab \& Odetokun, 2014). The greed and imperial arrogance of many landlords in many cities in Lagos have pitched them against their tenants with each camp seeking to outwit the other. By contrast, there are also very difficult tenants whose landlords are wary of because of past ugly experiences which make these home owners to either increase their vigilance and toughen their selection criteria or hand over the process of getting tenants into their rental properties to professional managers or agents (Akogun \& Ojo, 2013; Gbadegesin \& Oletubo, 2013).

Thus, landlord-tenant relations in Lagos State, as it happens in many developing and developed countries as well, are characterised by suspicion, mistrust, power tussle, and the struggle by each group to get the best out of the relationship at the expense of the other group (Bank, 2007; Gbadegesin \& Oletubo, 2013; Lemanski, 2009). This status quo leads to disputes that if not amicably resolved could further sour the relationship between the two groups, and turn violent, leading to the breach of public peace. While landlords could be forced to repossess their rental properties, tenants could be evicted and left with no home or business to turn to. This situation could create homelessness for many residents, because the abrupt closure of businesses and loss of jobs and at the same time lead to the loss of income for others. 
It, therefore, follows that if this huge housing shortage exists in Lagos, it is important that existing landlord-tenant relationship be maintained and landlord-tenant disputes be resolved amicably for the good of all stakeholders. Although there have been informal and interpersonal measures put in place by landlords and their tenants to resolve their disputes, the absence or not enough justiceability of these measures and the preservation of the landlord-tenant relationship might have prompted parties to take their disputes to the police or law courts with their attendant challenges. The need for speedy, fair and early resolution of landlord-tenant disputes in Lagos State led to the creation of the Citizens Mediation Centre (CMC) in 1999, which among other forms of disputes it was established to resolve, attends to disputes between landlords and tenants, and offers the alternative dispute resolution (ADR) mechanism of mediation to find solutions to the disputes between Lagos landlords and tenants. The CMC was designed to resolve landlord-tenant disputes in an inexpensive, speedy, impartial and confidential fashion, among other benefits that alternative dispute resolution is known to offer to disputants. This service by the CMC is very important to the continued prosperity, peace and progress of Lagos State and its growing population.

Mediation which the CMC uses in resolving landlord-tenant disputes has been seen as the ideal form of alternative dispute resolution mechanism for resolving disputes between landlords and tenants because of the several benefits it offers to disputants such as confidentiality, clarity, informality, justice, inexpensiveness, preservation of relationships, flexibility, equity and privacy, among others ( Lucas, 2014). Mediation is a structured negotiation process in which a neutral third party, chosen by two or more disputing parties, helps them to agree on a solution (Ilegbune, 2004; Law Reform Commission, 2008; National Judicial Institute, 2012). However, there has been an inadequate assessment of the workings of the CMC, particularly regarding its effectiveness in the use of mediation in resolving landlord-tenant disputes in the state. It is for these reasons that this study attempts to investigate the effectiveness of the Citizens Mediation Centre in resolving the disputes between landlords and tenants in Lagos State with a view to finding ways to improve the effectiveness of the Centre in its discharge of mediation in resolving landlord-tenant disputes in the state.

\section{CHARACTERISTICS OF LANDLORDS IN LAGOS STATE}

Lagos State is in Nigeria, a developing country. Hence, the discussion of the characteristics of landlords in Lagos State will be discussed from the perspective of landlords' characteristics in developing countries, suing empirical evidences. The characteristics of landlords in developing countries reveal that most of them operated in the informal rental market (Gunter, 2014). Many studies also show that most of these landlords were private individuals (Aluko \& Amidu, 2006; Gbadegesin \& Oletubo, 2013; Oladokun \& Ojo, 2011). These landlords, as Gunter (2014) observes, have a very high opinion of the service they are providing to the tenants and see their role as important service providers in an under-served market. Gunter adds that many of the landlords, using the example in South Africa, exhibited pride for the provision of this service and felt a sense of achievement because their rental units provided an alternative income stream for them in a largely poor environment.

The landlord-tenant relationship in most developing countries was based on suspicion. It involved a situation where tenants are mostly not allowed to assert their tenancy rights. Most tenancies in low-income private rental units and squatter settlements are not based on written agreements but, rather, are oral agreements between landlords and tenants. Often, landlords or their agents take measures which affect tenants adversely and are contrary to the oral agreement but there is usually little tenants can do to protect their rights. In Kenya, for instance, there have been many cases where landlords have sent gangs to forcibly evict tenants who are considered troublesome or capable of exposing landlords to the authorities (UN-HABITAT, 2003).

In developing countries rental market, under most rental agreements, the landlord is entitled to advanced rent from a new tenant of not more than two months standard rent. This could be more in some other places. The landlord can increase the rent through following laid-down procedures (Lagos Tenancy Law, 2011). Under the Lagos Tenancy Act 2011, for instance, tenants are to be protected from shylock landlords who demand multiple years of rent from their tenants. The law also seeks to ensure that a tenant enjoys the tenancy without undue interference from the landlord or his or her agents.

However, most rental housing in the developing world is in the informal sector, where rental agreements are mostly informal oral arrangements between tenants and landlords even in cases where tenancy involves formal houses. Thus, the rental housing market rarely operates according to the law. Nevertheless, public-sector landlords generally have proved to be willing to accept agreements which protect the rights of tenants (UN-HABITAT, 2008).

In further analysing the characteristics of landlords in many developing countries, the UN-HABITAT (2003) observed that one problem affecting landlords in these countries is that they are 'invisible'. Since most operate in the informal sector, they choose to disappear because they fear taxation or visits from building officials, and because no one talks about them. While this position may be exaggerated, it speaks about the reality in most developing countries particularly in Africa where landlords are small-scale and "petty" in nature 
Models for Investigating the Effectiveness of the Citizens Mediation Centre in the Resolution of ..

and do not have the capital to operate in the formalised rental sector but provide greater rental units to lowincome dwellers. Another reason for the invisibility of the landlords in most developing countries is that policy makers tend not to talk about the issue of renting compared with the vast amount of research carried out on selfhelp housing, making studies of landlords still scanty (UN-HABITAT, 2003).

Commenting further on their invisibility, UN-HABITAT (2003) citing research published in the last 20 years observes that most landlords in the developing world operate on a small-scale, are rather like their tenants, do not make much money and seem to be no more callous or calculating than anyone else. In short, they are invisible because in most respects they are like most citizens trying to eke out a living for themselves and their families.

While across the globe, private landlords include both rich and poor, individuals and companies, in most parts of the developing world, majority of landlords operate on a small scale and a few are rich (Gilbert, et al., 1997; Gilbert, 2010). In Latin American cities, although there is often a substantial middle-class rental market where the landlords are themselves middle class, the typical landlord is now a former self-help builder (UN-HABITAT, 2003). More and more landlords are now found in the self-help settlements renting out rooms in their modest homes. As self-help settlers, they tend to have similar backgrounds and incomes to their tenants. In Bogotá, Colombia, tenants and owners living in the same building tend to share very similar economic and social characteristics while in Caracas, Mexico City and Santiago, landlords and tenants seem to have similar per capita income. In Africa, most landlords have similar kinds of backgrounds to that of their tenants except that they tend to have lived in the city longer and are a little better off (Gilbert, 2010; UN-HABITAT, 2003). In Mali, for example, landlords tend to be significantly wealthier than their tenant households but are similar to them in other respects (Mugo, 2000). However, in Soweto and Johannesburg, studies show that landlords are among the poorest residents in the township. The more affluent households are either those with no backyard residents or those who accommodate only relatives or friends (Crankshaw et al., 2000). This picture is not different in Ghana where resident landlords in Kumasi tend not to be better off than their tenants and poorer than owners who do not let out rooms (UN-HABITAT, 2003). Admittedly in other parts of Africa, such as in Nigeria, Kenya, Egypt, and South Africa, landlords sometimes are more affluent than their tenants because they are either government officers or politicians or they belong to the business class (Gbadegesin \& Oletubo, 2013; Mugo, 2000).

Age seems to be the most consistent factor in distinguishing landlords from the rest of the population. This is because landlords tend to be older than other owner-occupiers and most times much older than most tenants (UN-HABITAT, 2003). Because of their age, landlords are much more likely to be retired, live in larger properties than other families and have lived longer in their current home (Yahya, 2002). In many developing countries, both men and women act as landlords, sometimes in partnership and sometimes on their own. Frequently, a woman may handle the tenants even when a man lives on the premises; what Kumar calls a 'woman-managed' household (Kumar, 2001). He also observed that most male landlords have a female partner but many widows and separated women rent out property too. But in many parts of the developing world such as in Africa, men are frequently the landlords either by building the houses directly or by inheriting it (Ogu, 1999). This is also seen in most parts of India where landlordism is predominantly a male-dominated occupation (Amis, 1998).

Regarding whether they were resident or absentee landlords, according to the UN-HABITAT (2003, 2008), most landlords operated on a small scale and tend to live on the premises. This is evidenced in big cities in Africa such as Cairo, Bamako, low-income suburbs of South Africa, Lagos and most parts of Latin America. However, as UN-HABITAT (2003) observes, exceptions appear to exist in the cities where more large-scale commercial landlords operate.

Understanding the motives of landlords, or why they become landlords, from studies carried out in most parts of Africa by the UN-HABITAT $(2003,2008)$, all landlords appeared to let property to obtain an income but the reasons they do so and the strategies that they follow in generating that income were reported as diverse. While for some landlords renting was a commercial exercise that involved the engagement of professional accountants and agents such as those found in the high- or middle-income city areas, many of the landlords in the low-income areas did not follow every facet of real professional practice in managing their rental units but were nonetheless driven by profit. However, it was reported by the UN-HABITAT that in most of the consolidated self-help areas of cities in developing countries, the typical landlord appears much less commercially oriented. While some are serious landlords because they are dependent on their rents in order to live, most certainly, are not 'professional' in their behaviour. In Resistencia (Argentina), it has been argued that, "small rentals are generally circumstantial." (UN-HABITAT, 2003). Renting is only done when a household finds it has extra space. Thus, for such landlords, renting is only a temporary arrangement, continued until older children want to return to the family fold. In Caracas and Mexico, landlords tend to enter and leave the activity according to need. They are not investing in housing mainly to rent it out and the use made of the accommodation may change frequently. It may have been built to accommodate the family, let out when the 
children leave home, and later used to put up members of the extended family (UN-HABITAT, 2003). The UNHABITAT also found out that letting property also provided a partial solution to the problem of what to do with a house if it cannot be sold. Some people inherit homes that they do not wish to live in. Others need to move house but are unable to sell their existing home in order to buy another. Many property owners have been forced to become landlords under such circumstances.

\section{TYPES OF TENANTS}

There are different types of tenants found in the rental sector. In order to ascertain the types of households to whom landlords are letting, studies have shown that tenants can be characterised by variables such as their age, sex, marital status and social status (Gunter, 2014; UN-HABITAT/UNESCAP, 2008). In a study carried out in Dublin, Memery \& Kerrins (2001) described the tenants that landlord let their rental units to as:

1. People with children and couples (families with young and/or older children)

2. The elderly

3. Childless couples

4. Single parents

5. Middle-aged single

In Africa, with a younger population and depending on the neighbourhood, tenants are seen to be upwardly mobile graduates, students, traders or business people and settlers from rural areas who have come to live and work in the city (UN-HABITAT, 2008). Some studies carried out in some developing countries identified the types of tenants found in such rental markets. These include low-income households that cannot presently afford to own their own homes due to financial constraints; urban migrants who prefer auspiciously located rental accommodation close to their workplaces or their businesses and that offers them flexibility; young people who value their independence, freedom and mobility, and many individuals who choose to spend their money on other priorities rather than on home ownership (Gbadegesin \& Oletubo, 2013; Gunter, 2014). For these people, rental properties offer them more benefits and freedom that they may not get having ownership of them outright. Some other types of tenants found are better-off and live in the major cities of their countries while generally tenants found in most countries are middle class and low-income earners.

While most tenants are young, many old people can also be found among the tenant population, particularly in old inner-city areas. Mostly households that consist of two adults without children or other dependants may tend to rent while larger households typically tend to be owner-occupiers. This might be linked, of course, to other factors, such as the age or income of the household head, but it is not wholly surprising that, in cities where self-help ownership offers more space than rented accommodation, large households move into ownership (UN-HABITAT, 1989). Generally, as the UN-HABITAT (1989) noted, tenants can be found among all income groups, at any age, among different kinds of household and among large families of all sizes and in different kinds of rental property.

It has rarely been possible to compare studies of effectiveness, since few have used common criteria for indicating effectiveness (Campbell, 1973; Steers, 1975), and effectiveness has been linked with a wide variety of organisational phenomena and enjoyed a wide variety of perspectives. Difficulty in empirically assessing organisational effectiveness has arisen because no one ultimate criterion of effectiveness exists. Instead, organisations may pursue multiple and often contradictory goals (Dublin, 1976; Hall, 1978), effectiveness criteria may change over the life cycle of an organisation, different constituencies may have particular importance at one time or with regard to certain organisational aspects and not others, criteria at one organisational level may not be the same as those at another organisational level, and the relationships among various effectiveness dimensions may be difficult to discover.

Therefore, while there is no universality on the best of dimensions for measuring organisational effectiveness, the three dimensions that predominate works that measured organisational effectiveness include goal achievement or outcome criterion, process criterion and resource acquisition criterion. Scholars who advocated goal achievement argue that accomplishment of goals should be the defining characteristic of organisational effectiveness. However, criticisms trailing this position were hinged on the following arguments: 1. There is a focus on official or management goals to the exclusion of the organisational member, organisational constituency, and societal goals

2. There is neglect of implicit, latent or informal procedures and goals

3. There is neglect of the multiple and contradictory nature of organisational goals;

4. Environmental influences on the organisation and its goals are ignored

5. Organisational goals are retrospective and serve to justify organisational action, not to direct it; and

6. The fact organisational goals change as contextual factors and organisational behaviour change ( Pfiffner, 1977) 
An alternative to the goal model is the system resource model or the natural systems model introduced by Yuchtman and Seashore (1967). This approach focuses on the interaction of the organisation with its environment, and defines organisational effectiveness as the ability of the organisation to exploit its environment in the acquisition of scarce and value resources. Organisational inputs and acquisition of resources replace goals as the primary criteria of effectiveness. This model, too, has been criticised as having the following flaws:

1. Efficiency and effectiveness are not separated under this model

2. Focusing on inputs alone may have damaging effects on outputs

3. The model assumes that the only valuable aspects of organisations are those which aid input acquisition

4. Only the organisational directors' viewpoint is taken

5. It is similar to the goal model since increasing inputs is an organisational operative goal

6. This approach is inappropriate when considering non-profit organisations (Molnar \& Rogers, 1976).

Another model relies on organisational processes as defining characteristics of effectiveness. Steers (1977) views effectiveness as a process and not an end state. Pfeffer (1977) suggested that to study organisational effectiveness, it was important to consider the process by which organisations articulate preferences, perceive demands, and make decisions. The process model has been criticised on the bases that it is difficult to monitor organisational processes, it ignores the high cost of gathering data on processes, it focused on means to the neglect of ends and it ignores the possibility of the processed data being inaccurate (Campbell, 1977, 1978).

It is important to mention that organisational effectiveness criteria are likely to differ depending on whose viewpoint is taken, that is, their sources since effectiveness criteria always reflect someone's values and biases. Thus, there is conflict about who should determine effectiveness criteria and who should provide data for their measurement.

For this study, the goal achievement/outcome criterion, process criterion and the vision and objectives of the CMC have been adopted as criteria for the design of the questionnaire instrument and the development of the In-depth interview guide and the Key Informant Interview guide to elicit robust viewpoints in order to examine the effectiveness of the Citizens Mediation Centre and how the institution's effectiveness can be enhanced.

The goal achievement criterion was adopted in order to examine the goals achieved so far by the CMC in the area of landlord/landlady-tenant dispute resolution by engaging selected respondents made up of landlords or landladies and tenants to answer questions tailored to discern the goals achieved by the Centre, and develop dimensions by which its effectiveness can be examined and enhanced. The process model was to correct whatever flaws the goal model has by examining the dispute resolution process of the Centre and to understand its strengths and weaknesses as viewed by landlords or landladies and their tenants who have attended the Centre's mediation programmes between the periods of 2006-2016. These models are to be supported by an examination of the vision and objectives of the CMC and an assessment of the Centre in fulfilling these res.

\section{CONCLUSION}

The paper has emphasized the challenges of housing in Lagos State of Nigeria, and how the problems of housing have created avoidable conflictual relationships between landlords and tenants. The models for investigating the effectiveness of the Citizens Mediation Centre as an alternative dispute resolution centre needs to be constantly reviewed for the purpose of achieving peace and stability in the tenancy relationship as it relates to the private rental housing system because of its importance for the development of Lagos State and the peaceful co-existence of landlords and tenants in the state. These models can also be adopted by other cities in addressing the ever-present conflict between landlords and tenants, particularly in developing countries.

\section{REFERENCES}

[1]. Adelaja, B. (2014). Lagos unveils plans to register 21 million residents. Vanguard Newspapers. Retrieved from www.vanguardngr.com/2014/02/lagos-unveils-plans-register-21m-residents-ibirogba

[2]. Akogun, I. T. \& Ojo, O. (2013). The consequences of tenant eviction in Ilorin, Nigeria: Estate surveyors and tenants' perspectives. Journal of Research in Economics and International Finance (JREIF) Vol. 2 (5), 79-87.

[3]. Citizens Mediation Centre. (2016a). Historical background and mandate of the CMC. Retrieved from http://cmc.com.ng/mediation\%20centres.html

[4]. Citizens Mediation Centre. (2016b). The Office of the Citizens Mediation Centre. Retrieved from http://lagosministryofjustice.org/offices/citizens-mediation-centre/

[5]. Condliffe, P. (2003). Conflict management: A practical guide. (Second edition). Sydney: Butterworths. 
Models for Investigating the Effectiveness of the Citizens Mediation Centre in the Resolution of ..

[6]. Crankshaw, O., Gilbert, A.G., \& Morris, A. (2000). Backyard Soweto. International Journal of Urban and Regional Research, Vol. 24, 841-857.

[7]. Economist Intelligence Unit. (2012). Meeting housing needs in Lagos. EIU Policy Brief, Issue 1, December.

[8]. Gbadegesin, J. T. \& Oletubo, A. (2013). Analysis of tenant selection criteria in an emerging rental market. Global Journal of Management and Business Research, Volume 13 (7).

[9]. Gilbert, A. (2010). A policy guide to rental housing in developing countries (Volume 1). Kenya: United Nations Human Settlements Programme (UN-HABITAT).

[10]. Gilbert, A., Mabin, A., McCarthy, M. \& Watson, V. (1997). Low-income rental housing: Are South African cities different. Environment and Urbanization, Vol. 9, No.1, 133-148

[11]. Gunter, A. (2014). Renting shacks: Landlords and tenants in the informal housing sector in Johannesburg South Africa. Urbani Izziv, Volume 25, (Special issue). DOI: 10.5379/urbani-izziv-en-2014-25supplement-007

[12]. Ilegbune, U. C. (2004). Mediating community/company environmental disputes in the oil and gas industry: A guide for promoting environmental mediation in emerging economies with focus on Nigeria. (Master's Dissertation). Centre for Energy, Petroleum and Mineral Law and Policy, University of Dundee.

[13]. Lagos State Tenancy Law. (2011). Lagos State of Nigeria Official Gazette. Lagos: Lagos State Government.

[14]. Law Reform Commission. (2008). Consultation paper: Alternative dispute resolution. Dublin, Ireland: Author.

[15]. Law Reform Commission. (2010). Alternative dispute resolution: Mediation and conciliation. Dublin, Ireland: Author.

[16]. Lemanski, C. (2009). Augmented informality: South Africa's backyard dwellings as a by-product of formal housing policies. Habitat International 33, 472-484.

[17]. Lucas, B. (2014). Alternative dispute resolution for businesses in developing countries. GSDRC Helpdesk Research Report no. 1148. University of Birmingham.

[18]. UN-HABITAT. (1989). Strategies for low-income shelter and services development: The rental-housing option. Nairobi: UN-HABITAT. Retrieved from http://www.chs.ubc.ca/archives/files/HS-172.pdf

[19]. UN-HABITAT. (2006). Rental housing, an essential option for the urban poor in developing countries. Retrieved from http://www.unhabitat.org/downloads/docs/3588_62479_655.pdf (5th April 2012)

[20]. UN-HABITAT/United Nations Economic and Social Commission for Asia and the Pacific (UNESCAP). (2008). Housing the poor in Asian cities. Rental Housing: A much neglected housing option for the poor. Bangkok, Thailand: Authors.

[21]. Wahab, B., \& Adetunji, O. (2015). Conflict resolution strategies on community-driven projects in private and public housing estates in Lagos State, Nigeria. African Journal for the Psychological Study of Social Issues, Vol.18, No.2, 42-70.

[22]. Wahab, B. \& Odetokun, O. (2014). Indigenous approach to housing-induced domestic conflict management in Ondo City, Nigeria. Journal of Sustainable Development, Vol. 7, No.4, 28-46. 